\title{
La no ejecución de un Laudo Arbitral Comercial Internacional como expropiación indirecta
}

\author{
James A. Graham* \\ Carlos Treviño Vives**
}

\begin{abstract}
SUMARIO
1. Introducción 2. existencia de una decisión arbitral en el contexto internacional. 3. existencia de una expropiación indirecta en el caso de no-respeto de un laudo internacional. 4. conclusión.
\end{abstract}

\section{INTRODUCCIÓN}

Desde hace tiempo se ha presentado la interrogante de si una decisión judicial o arbitral desfavorable podría ser constitutiva de una expropiación indirecta bajo el amparo de la Convención de Washington, el Tratado de Libre Comercio de América del Norte (TLCAN) o un Tratado Bilateral de Protección de Inversión Extranjera (BIT). El hecho es que varios Estados, no obstante sus obligaciones bajo los tratados internacionales, se aprovechan de sus tribunales locales para impedir o dificultar el proceso arbitral, en particular vía antisuit injunc$t_{\text {tions }}{ }^{1}$ o para anular los laudos. La consecuencia directa es que la

- Socio de Lobo \& Graham y Asociados SC. Presidente de la Academia de Derecho internacional de la Universidad de Monterrey; miembro del Instituto de Investigaciones Juridicas de la Facultad de Derecho y Criminologia de la Universidad Autónoma de Nuevo León. Graltam@lobo-graham.com

** Asociado de Lobo \& Graham y Asociados SC. Trevino@lobo-graham.com 
parte actora se ve frustrada en su expectativa de obtener la indemnización reclamada. Tal es particularmente la situación en materia de inversión extranjera. Por lo tanto, no es sorprendente ver a los afectados sostener que las mencionadas situaciones son nada más y nada menos que expropiaciones indirectas.?

Ahora bien, el concepto de expropiación indirecta implica que hay propiedad a expropiar. ¿Una decisión judicial o arbitral puede ser considerada como una propiedad? La tendencia en el derecho comparado es en el sentido positivo. Es así que en el asunto Saipem, ${ }^{3}$ el Tribunal Arbitral consideró que la no-ejecución de un laudo arbitral por el Estado receptor de inversión es constitutiva de una expropiación, citando varias otras decisiones internacionales en este sentido. En otras palabras, los derechos derivados de las decisiones judiciales o arbitrales son propiedad susceptible de ser expropiada. ${ }^{4}$

Si el laudo se puede considerar como propiedad, aun falta el argumento para considerarlo como una inversión. Ahí también es menester citar el asunto Saipem, en el cual en realidad el Tribunal Arbitral no contestó directamente, sino consideró que el laudo es la consecuencia de un entorno contractual que, visto en su conjunto, es una inversión extranjera: ${ }^{5}$

113. The Tribunal agrees with Bangladesh that the rights arising out of the ICC Award arise only indirectly from the investment. Indeed, the opposite view would mean that the

1. GAILLARD, EMMANUEL. "Anti-suit injunctions et reconnaissance des sentences anulíes au siege: une evolution remarquable de la jurisprudence americaine" En: Journal du Dmit lnternational. Paris, 2003. p. 1105; GAILLARD, EMMANUEL "Anti-suit injunctions issued by arbitrators". En VAN DER BERG, ALBERT International arbitration 20)6: Back to the hasic. 1a edicion. Paris: ICCA, 2007. p. 235.

2. Sobre la problemática: MOURRE, ALEXIS "La responsabilidad del Estado por incumplimiento de su obligación de ejecutar un laudo extranjero". En SOTO, CARLOS. El arbitraje en el Perú y en el mtmdo. I" edición. Lima: Editora Juridica, 2008, p. 574.

3. Saipem Spd is The People's Republic of Bangladesh. Decisión sobre la jurisdicción ARB/05/07, 21/3/07 (Kaufmann Kohler, Schrcuer; Otion).

4. Hem

5. Sobre las múltiples apreciaciones en relación con la noción de inversión, véase YALA. FAROUK. "La notion d'investissement dans la jurisprudence du CIRDI". En LEBEN, CHARLES Le conten tieux arbitral transnational relative a la imestissement. Paris: LGDJ, 2006, p. 281. 
Award itself does constitute an investment under Article 25(1) of the ICSID Convention, which the Tribunal is not prepared to accept .

114. However, as already mentioned, the notion of investment pursuant to Article 25 of the ICSID must be understood as covering all the elements of the operation, that is not only the ICC arbitration, but also inter alia the Contract, the construction itself and the Retention Money.

Ahora bien, si está aclarado que el laudo puede ser parte de un entorno inversionista, se queda entonces la problemática de la nulidad del laudo pronunciada en el Estado receptor de la inversión. En efecto, si el Estado sede del arbitraje es también el Estado receptor, y que ha anulado un laudo, se abre la pregunta si éste laudo existe (2) por efectos de un procedimiento arbitral sobre inversión extranjera, y más precisamente su la decisión judicial de anular un laudo puede ser constitutivo de una expropiación indirecta (3).

\section{EXISTENCIA DE UNA DECISIÓN ARBITRAL EN EL CONTEXTO INTERNACIONAL}

Es alrededor de la problemática si es posible o no ejecutar en un Estado un laudo que fue anulado en otro Estado (normalmente el Estado sede del arbitraje), que se ha intentado dilucidar cuál es la naturaleza de una decisión arbitral. Una corriente doctrinal fuerte aboga por establecer que el laudo tiene una existencia "subjetiva", en la medida que no hay existencia "objetiva" del laudo en el Estado sede del arbitraje y, por consecuencia, corresponde a cada Estado en donde se busca la ejecución decidir si reconoce o no la existencia del laudo. Tal postura puede sostenerse de la jurisprudencia de la Corte de casación francesa. El precedente histórico es el fallo francés Hillmarton que afirma esta posibilidad conforme al siguiente razonamiento. 
...un laudo rendido en materia internacional en un Estado extranjero no queda integrado en el orden jurídico de ése Estado, y por tanto su existencia permanece no obstante su anulación en el Estado sede del arbitraje, y consecuentemente tiene que ser ejecutado, siempre y cuando su reconocimiento en Francia no sea contrario al orden público. ${ }^{6}$

Recientemente, la misma Corte francesa fue un paso más allá, estableciendo que: "un laudo arbitral no está integrado en nin-

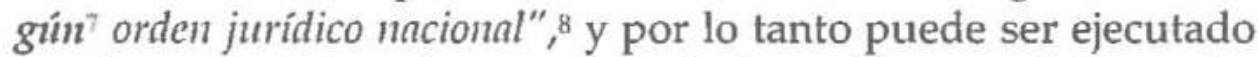
con base en el derecho común más favorable que el Convenio Neoyorquino, no obstante el pronunciamiento de la nulidad del laudo en el Estado sede del arbitraje.

Sin embargo, la mencionada decisión Putrabali también agrega una calificación jurídica, estableciendo que un laudo (internacional) es una "decisión jurídica internacional", cuya validez tiene que ser comprobada según la lex fori del Estado en donde se busca la ejecución. Este calificativo de "decisión judicial" implicaría entonces que un laudo tiene una existencia objetiva cuya realidad no se puede negar. Ahora bien, si una verdadera decisión judicial puede ser anulada por los tribunales superiores en donde se hizo el procedimiento, no cabe duda que ningún otro Estado puede ejecutar tal decisión, porque ya no existe. Por corolario, eso daría pauta a sostener que un laudo anulado en el Estado sede ya no podría ser ejecutado en otro país, y de esta forma se negaría la concepción subjetiva del laudo que tanto las decisiones Hillmarton como Putrabili parecen defender cuando sostienen que "un laudo no está integrado en cualquier orden jurídico nacional”. EMMANUEL GAILLARD intenta reconciliar ambos puntos al considerar que el laudo tiene una existencia objetiva en un "orden jurídico autónomo", constituido por la "comunidad de todos los Estados" y a cada Estado corresponde

6. 23/3/94, Rev arb, 1985, 327. Para una crítica fuerte del derecho francés del arbitraje en relación con el concepto de la "autonomia", véase KASSIS, ANTOINE. L'antonomie de l'arbitrage comercial internutienal. Paris: L'Harmattan, 2005, pp 499 y ss.

7. El resaltado es nuestro.

8. Civ. Putrabuli, 29/6/2007. Version en inglés, Arbitration International, 2008, p. 293. 
subjetivamente reconocer o no tal orden jurídico. ${ }^{9}$ No es posible en el margen limitado de éste artículo disertar sobre una hipótesis tan compleja como lo es la de una posible existencia o no de tal "tercer orden jurídico", 10 sino de reconocer que en una apreciación subjetiva, un laudo anulado puede ser una expropiación indirecta en materia de inversión extranjera, como se puede por ejemplo verificar en el asunto Saipem.

Saipem es una empresa italiana que en 1990 celebró un contrato con Petrobangla, una empresa estatal de Bangladesh, para realizar la construcción de un gasoducto. El proyecto estaba contemplado para terminarse en 1992, pero debido a la oposición de un sector de la población se demoró su finalización. Saipem y Petrobangla acordaron una extensión al plazo; sin embargo, atrasos significativos continuaron presentándose e hicieron surgir una controversia derivada de los costos adicionales del proyecto.

El aspecto central de la controversia fue la negativa de Petrobangla de pagar los costos adicionales que se alega se comprometió a pagar. Se inició un procedimiento de arbitraje siguiendo las reglas de la Cámara de Comercio Internacional (CCI). En noviembre de 1997, Petrobangla inició procedimientos para revocar la autoridad del Tribunal Arbitral ante tribunales locales de Bangladesh, alegando mala conducta de los árbitros y violación a sus derechos procesales debido a la negación de distintas mociones que solicitaron. Ante esto, la Suprema Corte de Bangladesh resolvió restringir el acceso de Saipem al Tribunal Arbitral.

En abril 5 de 2000, las cortes locales revocaron la autoridad del Tribunal Arbitral," sosteniendo que el arbitraje se había lle-

9. “The representations of international arbitration". New York law journal, 4 de octubre de 2007.

10. Para un resumen sobe esta cucstión, véase GAILLARD, EMMANUEL "Souveraineté et autonomic: réflexions sur les representations de l'arbitrage international" En: Jesurnal du Droit International. Paris, 2007, p. 1163.

11. "El Estado no puede escapar a su responsabilidad internacional por $\mathrm{cl}$ argumento de que sus tribunales se pronunciaron en su favor. El juez del tratado elimina al juez del contrato. El derecho internacional vence al derecho nacional Véase GRAHAM, JAMES. “Dónde se queda la legitima expectativa de los Estados en los arbitrajes sobre inversión extranjera?" En Revista Mfexicuna de Derecho de Derechu Internacional Privado. 2004, p. 146.m 
vado a cabo de forma inapropiada, y además se había apartado de la ley. En la sentencia se resolvió también que la negativa de admitir cierta evidencia y la exclusión de documentos fue lo que se tomó en cuenta para llegar a las conclusiones. Sin embargo, el Tribunal Arbitral decidió continuar con el procedimiento, mencionando que el reemplazo de los árbitros es jurisdicción exclusiva de la CCI y no de los tribunales locales de Bangladesh. En el laudo final, se resolvió que Petrobangla incumplió con sus obligaciones contractuales al no pagar la compensación por los trabajos adicionales realizados. Ante esto, Petrobangla decidió acudir a los tribunales judiciales para solicitar la nulidad del laudo, y el 21 de abril de 2004 la Suprema Corte de Bangladesh rechazó la solicitud de Petrobangla, argumentando que un laudo que no existe no es susceptible de ser ni anulado ni ejecutado. En efecto, el argumento de la jurisdicción local fue que la autoridad del tribunal arbitral ya había sido revocada con anterioridad.

En otras palabras, Bangladesh considera que la existencia del laudo depende única y exclusivamente de su orden jurídico si la sede es en ese país. Ahora bien, el tribunal arbitral no compartió esa visión, siguiendo así lo que se estableció en el fallo arbitral Salini. ${ }^{12}$ Recordamos que en éste asunto los árbitros declararon:

127. For the reasons set out below, the finding of the tribunal on this issue is that an arbitral tribunal constituted in such circumstances has a discretion as to whether or not it should comply with such an order.

128. An international arbitral tribunal is not an organ of the state in which it has its seat in the same way that a court of the seat would be. The primary source of the Tribunal's powersis the parties' agreement to arbitrate. An important consequence of that is that the Tribunal has a duty vis a vis the parties to ensure that their arbitration agreement is nos

12. Salini Construttori SPA us The Federal Democratic Republic of Ethiopia. Decisión sobre jurisdicción, 7/12/01 (Gaillard. Bemardini, Bunni), Revistu Latinoamericana de Medicación y Arbitraje, 2001, p.159. Para un comentario critico de la decisión, véase SCHWARTZ, ERIC. "Do international arbitrators have a duty to obey the orders of courts at the place of the arbitration?" En Global Reflections on International Lan; Commere and Dispute Resolution, Liber Amicorum in Honour of Robert Briner. ICC Publishing, 2005, p. 795. 
frustrated. In certain circumstances, it may be necessary to decline to comply with to an order issued by the court of the seat, in the fulfillment of the Tribunal's larger duty to the parties.

129. Of course, this is not to say that a contract, including an arbitration agreement, has a validity that is independent of any legal order. Indeed, a contract derives its binding force from its recognition by one or more legal orders. However, an agreement to submit disputes to international arbitration is not anchored exclusively in the legal order of the seat of the arbitration. Such agreements are validated by a range of international sources and norms extending beyond the domestic seat itself.

138. ... The Tribunal owes a duty to the parties to ensure that their agreement to submit disputes to international arbitration is rendered effective even where that creates a conflict with the courts of the seat of the arbitration.

139. ... The fact remains that the law of the seat and the decisions of the courts of the seat are important factors that must be taken into account. The Tribunal would be slow to render an award that is likely to be set aside at the seat, taking into account the principle according to which the Tribunal must make every effort to render an enforceable award.

142. This does not mean, however, that the arbitral tribunal should simply abdicate to the courts of the seat the tribunal's own judgment about what is fair and right in the arbitral proceedings. In the event that the arbitral tribunal considers that to follow a decision of a court would conflict fundamentally with the tribunal's understanding of its duty to the parties, derived from the parties' arbitration agreement, the tribunal must follow its own judgment, even if that requires non-compliance with a court order.

143. To conclude otherwise would entail a denial of justice and fairness to the parties and conflict with the legitimate expectations they created by entering into an arbitration agreement. It would allow the courts of the seat to convert an international arbitration agreement into a dead letter, with intolerable consequences for the practice of international arbitration more generally. 
144. This conclusion is consistent with principles that are already well established in international arbitration. In particular, it is clear from arbitral case law that the obligations to make every effort to render an enforceable award does not oblige an arbitral tribunal to render awards that are fundamentally unfair or otherwise improper. An arbitral tribunal should not go so far as to frustrate the arbitration agreement itself in the interest of ensuring enforceability. Such an outcome would be, to say the least, a paradox.

Como se puede desprender de lo anterior, a final de cuentas quien decide que hay arbitraje y que hay una decisión final es el propio tribunal arbitral, y consecuentemente un tribunal judicial local no puede "invalidar" un procedimiento arbitral, y tampoco considerar que si el procedimiento fue "invalidado" no existe por tanto un laudo. Sin embargo, nadie impugna el hecho que el Estado sede del arbitraje sí tiene la facultad de anular el laudo, pero sólo de manera subjetiva. Esto quiere decir que si por el Estado sede el laudo anulado ya no existe, los demás Estados son libres de constatar la existencia o no del laudo anulado. Esta problemática se cristalizó también en el caso Saipem. En efecto, Saipem sostuvo ante el tribunal arbitral del CIADI, ${ }^{13}$ que el hecho de que los tribunales de Bangladesh interfirieron de manera "ilegal" en el procedimiento arbitral CCI y que desconocieron la existencia del laudo, se hizo una "confiscación" de las sumas otorgadas a Saipem y consecuentemente había una confiscación indirecta:

129. According to Saipem, its case is based on Petrobangla's alleged unlawful disruption of the ICC arbitration, on the alleged interference by the domestic courts with the Arbitration, and on the de facto annulment of the ICC award. These acts allegedly deprived Saipem of the sums awarded to it by the ICC Award, and thus amount to an illegal expropriation in breach of Article 5 of the BIT

13. Sobre el funcionamiento del CIADI, cfr. RODRIGUEZ JIMÉMEZ, SONIA. El sistema arbitral del ClADI. 1" ediciỏn. México: Porrua, 2006; GÓMEZ-PALACIO, IGNACIO. Derecho de los ncgocios internacionales. México: Porrúa, 2006.

232 Revista Ecuatoriana de Arbitraje 
(Response J p.4, para 15). At the hearing, Saipem further submitted that a State's disavowal of its undertaking to arbitrate a contractual dispute may have a "confiscatory effect" (Tr J. II, 50:16-2332) and summarized its case as follows:

The claims which are brought before the tribunal are a claim for expropriation in violation of Article 5 of the BIT. It is an expropriation which has resulted from a complex behavior of the whole state, which reneged on its obligations to enforce the arbitration award and to respect the proper conduct of the arbitration proceedings...

(Tr, J, II 52:12-18)

"The focus of the Claimant's is that its right to payment under the contract as ascertained by, and incorporated in the ICC Award has been expropriated by the unlawful decisions of the Bangladeshi courts that revoked the authority of the ICC arbitrators and declared the ICC award null and void, thus precluding its enforcement in Bangladesh or elsewhere. The net result of all of this was, obviously, to deprive the Claimant of the compensation for (the expropriation of) its investment"

Como se puede ver, el asunto Saipem puso a la luz la estrecha interacción de la teoría general del derecho arbitral, la calificación jurídica del laudo, la existencia o no de un orden jurídico "autónomo" y el papel del Estado sede en el procedimiento arbitral. Como lo veremos más adelante, el tribunal CIADI consideró que pudiera existir una expropiación indirecta si los hechos alegados por Saipem se comprobaban. Tal decisión obviamente niega al Estado sede la posibilidad de afirmar la integración del laudo en su orden jurídico. Es cierto que tiene la posibilidad de anular el laudo según sus leyes, pero no puede impedir que otros Estados, u otros tribunales arbitrales reconozcan su existencia. Y no cabe duda que tal razonamiento tiene sólo una salida: la abolición de la noción del Estado sede, tal como lo hemos defendido en varias ocasiones. ${ }^{14}$ Sin embargo, fuerza es consta-

14. PEREZNIETO, LEONEL Y GRAHAM, JAMES. "Hacia una verdadera justicia transnacional del siglo 21 " en SOTO, CARLOS. El arbitraje en Peri y el mundo. Lima: Instituto Peruano de Arbitraje, 2008, p. 745; PEREZNIETO, LEONEL Y GRAHAM, JAMES. “¿La muerte programada del Estado sede del arbitraje?", en Picand, Estudios de arbitraje, Chile: Editorial Juridica de Chile, 2006, p. 595. 
tar que el concepto de Estado-sede está -aún- bien anclado en el derecho positivo. ${ }^{15}$

Sin embargo, el tribunal arbitral del CIADI en el asunto Saipem, adoptó la postura que la existencia de un laudo se aprecia de manera subjetiva y que, consecuentemente, un laudo anulado en el Estado sede puede tener, sin embargo, una existencia objetiva y por lo tanto se puede considerar que hay una expropiación indirecta si el Estado no quiere reconocer el laudo.

\section{EXISTENCIA DE UNA EXPROPIACIÓN INDIRECTA EN EL CASO DE NO RESPETO DE UN LAUDO INTERNACIONAL}

El tribunal arbitral del CIADI en la disputa en contra de Bangladesh señaló en primer lugar que es ampliamente aceptado en el derecho internacional que los derechos inmateriales pueden ser expropiables. De esta forma, un laudo arbitral de la $\mathrm{CCI}$ o los derechos determinados por él pueden ser sujetos a una expropiación. En este sentido, el tribunal arbitral citó jurisprudencia de la Corte Europea de Derechos Humanos para reforzar su postura. En efecto, aunque el caso Allard vs Sweden ${ }^{16}$ de la Corte Europea de Derechos Humanos, citado por el tribunal arbitral, no se refiere expresamente a la expropiación, se refiere a la interferencia estatal hacia una propiedad que fue demolida bajo las leyes de Suecia. En este sentido, resulta discutible la aplicación de la jurisprudencia de la Corte Europea de Derechos Humanos de la cual Bangladesh no es parte. Cierto es lo anterior puesto que la jurisprudencia de esta Corte se suscita e inscribe en un sistema convencional particular y en estricto sentido no es el reflejo del derecho internacional en general. ${ }^{17}$

El Tribunal Arbitral también consideró que el contrato entre Saipem y Petrobangla es una inversión tal y como se define en el

15. Cfr Por ejemplo: OLG Dresden, 31/1/07, SchiedsVZ, 2007. 327.

16. Caso $3517997,2003$.

17. Véase GRAHAM. JAMES ¿Dónde se queda...? cit. Nota II, p. 14. 
artículo 1 del tratado bilateral. ${ }^{18}$ Más aún, se consideró el concepto de inversión de tal forma que se incluye no sólo el contrato, sino los derechos que derivan de él, reconocidos por el laudo de la CCI. Por lo tanto, se consideró que la inversión se compone de la operación total: el contrato, la construcción del gasoducto y el arbitraje de la CCI. El Tribunal Arbitral finalmente estableció que los hechos demandados por Saipem son potencialmente capaces de constituir una expropiación de acuerdo a los lineamientos establecidos del artículo 5 del Tratado Bilateral de Inversión. ${ }^{19}$ Esto es, los hechos alegados por Saipem pueden contravenir a lo establecido por el tratado bilateral de inversión, dado que los derechos inmateriales reconocidos en el laudo de la CCI son una "propiedad" y pueden ser sujetos a una expropiación. Pero, ¿en verdad se puede hablar de una expropiación indirecta en el contexto que se analiza?

Definir la expropiación indirecta es complicado, debido a que muchas veces el objetivo es precisamente que la expropiación indirecta no sea estrictamente definida, sino dejar un concepto amplio sujeto a las interpretaciones de los tribunales correspondientes, se ha establecido como principio amplio abierto a la interpretación. ${ }^{20}$ En este contexto, el BIT entre Italia

18. "The term "investment" shall be construed to mean any kind of property invested before or after the entry into force of thus Agreement by a natural or legal persona being a national of one Contracting Party in the territory of the other in conformity with the laws and regulations of the latter. Without limiting the generality of the foregoing, the term investment comprises:

a) Movable and inmovable property, and any other rights in rem including insofar as they may be used for investment purposes, real guarantees on other property:

b) Shares, debentures, equity holdings and any other negotiable instrument or document of credit, as well as Government and public securities in general:

c) Credit for sums of money or any rights for pledges or services having an cconomic value connected with investment, as well as reinvested income as defined in paragraph 5 hereafter

d) Any right of a finantial nature accruing by law or by a contract and any licence, concession or franchise issued in accordance with current provisions governing the exercise of business activities, inclu. ding prospecting for, cultivating, extracting and exploiting natural resources".

19. "The investments to which this agreement relates shall no be subject to any measures which might limit permanently or temporarily their joined rights of ownership, possession, control or enjoyment. save where specifically provided by law and judgment or orders issued by Courts or Tribunals having jurisdiction.

(2) Investments of investors of one of the Contracting parties shall not be directly or indirectly nationalized, expropriated, requisitioned or subject to any measures having similar effects in the territory of the other Contracting Party, except for public purposes, or national interest, against immedinte full and effective compensation, and on condition that these measures are taken on an non-discriminatory basis and in conformity with all legal provisions and procedures" 
y Bangladesh alude a la expropiación indirecta en su artículo 5 en los siguientes términos:

The investments to which this agreement relates shall no be subject to any measures which might limit permanently or temporarily their joined rights of ownership, possession, control or enjoyment, save where specifically provided by law and judgment or orders issued by Courts or Tribunals having jurisdiction.

Investments of investors of one of the Contracting parties shall not be directly or indirectly nationalized, expropriated, requisitioned or subject to any measures having similar effects in the territory of the other Contracting Party, except for public purposes, or national interest, against immediate full and effective compensation, and on condition that these measures are taken on an non-discriminatory basis and in conformity with all legal provisions and procedures

El mencionado artículo 5 del BIT entre Italia y Bangladesh no establece un marco conceptual rígido para la expropiación indirecta. También se deja en forma amplia las medidas, acciones o conductas que pudieren tener un efecto similar. En este contexto, han existido procedimientos arbitrales en donde el Tribunal otorga su propia definición para enmarcar conceptualmente la expropiación indirecta. Ejemplo de lo anterior es el caso Tecmed en donde se señaló que:

Si bien en un sentido formal la expropiación importa la apropiación forzada por el Estado de la propiedad tangible o intangible de particulares a través de actos administrativos o acción legislativa a ese efecto, el término también cubre situaciones que constituyen una expropiación de facto, en las que tales actos o legislación transfieren los bienes que constituyen su objeto a tercero o terceros distintos del Estado expropiador, o cuando dicha legislación o actos privan de tales bienes a los sujetos que los sufren, sin atribuirlos a terceros o al propio Estado. ${ }^{21}$

20. DOLZER, RUDOLF Indirect expropriation: New deselopments? Disponible en: http:/iwww 1.law.nyu edu/journals/envtliaw/issues/voll1/1/dolzerpdr 2002, p. 69. 
La anterior definición se inspiró en el laudo del caso Metalclad,, 22 en donde la evolución del concepto de expropiación se desarrolló de tal forma que incluye cualquier interferencia con la propiedad, o la expropiación indirecta o medidas equivalentes. Además se enfocó de manera exclusiva en los efectos de la medida gubernamental y para llegar a su conclusión no hizo referencia a opiniones o jurisprudencia previa:

Por lo tanto, la expropiación en el TLCAN incluye no sólo la confiscación de la propiedad de manera abierta, deliberada y con conocimiento de causa, tal como una confiscación directa o una transferencia formal u obligatoria de títulos a favor del Estado receptor, pero también una interferencia disimulada o incidental del uso de la propiedad que tenga el efecto de privar, totalmente o en parte significativa, al propietario del uso o del beneficio económico que razonablemente se esperaría de la propiedad, aunque no necesariamente del beneficio obvio del Estado receptor. ${ }^{23}$

Metalclad amplió el marco protector para el inversionista y se ha convertido en una pauta a seguir por distintos procedimientos de arbitraje. En un sentido similar, en el caso Waste Management ${ }^{24}$ se consideró que para que exista una expropiación no es necesaria una transferencia del derecho a la propiedad, sino que es suficiente con que se prive del derecho.

Todo lo anterior nos conduce a las herramientas que se han utilizado para analizar una posible medida equivalente a la expropiación, o expropiación indirecta. Una de ellas es a través de la observación del efecto que causa la medida del Estado en la propiedad del inversionista, la llamada doctrina sole effect. Por otra parte, es importante conocer también el contexto en el que se desenvuelve la medida estatal, y para ello se recurre al balan-

21. Véase Técnicas Medioambientales TECMED SA vs Estados Unidos Afexicanos. 29/0503. ARB(AF)/002 Párrafo 114 (Grigeria Naon, Fernández Rozas, Bemal Verea).

22. Mfotalclad corporation is los Estados Unidos Afexicunos. ARB (AF)/97/I. 30 de agosto de 2000, Pairrafo 103 (Lauterpacht,Civiletti, Siq̨uciros).

23. Ihidem Párrafo 103.

24. 30 de abril de 2004 (Crawford, Civilctti, Magallón). 
ced approach. ${ }^{25}$ También hay quien distingue entre el sole effect doctrine y el appropiation approach ${ }^{26}{ }^{26}$ necesitando esta última un beneficio estatal o de cualquier persona o entidad relacionada, interpretación que se utiliza escasamente; de esta forma, el Tribunal Arbitral en el caso Eudoro Armando Olguín señaló que:

For an expropriation to occur, there must be actions that can be considered reasonably appropriate for producing the effect of depriving the affected party of the property it owns, in such a way that whoever performs those actions will acquire, directly or indirectly, control, or at least the fruits of the expropriated property. Expropriation therefore requires a teleologically driven action for it to occur; omissions, however egregious they may be, are not sufficient for it to take place. ${ }^{27}$

Para interpretar el alcance de las normas relativas a la expropiación indirecta, hay quien también apuesta por consideraciones teleológicas 28 y siguiendo el artículo 31 de la Convención de Viena sobre el derecho de los tratados, el intérprete se debe enfocar al objeto y propósito del tratado, y si los tratados bilaterales de inversión son realizados para promover y facilitar la inversión, la interpretación deberá favorecer al inversionista, expandiendo sus derechos para facilitar el flujo de inversión extranjera. Sin embargo, esta visión no toma en cuenta el papel de los Estados en la promoción de la inversión extranjera que también les beneficia a ellos; más aún, se es omiso en señalar que la promoción exacerbada de la inversión extranjera puede ocasionar que el Estado viole sus obligaciones, por ejemplo, en virtud del derecho internacional de los derechos humanos.

El anterior repaso somero de la construcción del concepto de la expropiación indirecta nos conduce a analizar el caso de

25. International investment law; OECD, p. 62.

26. NEWCOMBE,ANDREW PAUL "The boundaries of regulatory expropriation in international law"En ICSID Review Foreign Investment Law Journal. 2005, p. 17.

27. Olguin is Paraguay: ARB/98/5, 26/7/01. (Oreamuno, Mayora, Rezek).

28. DOLZER,RUDOLF, Op. Cit. Nota 20 p. 73. 
Saipem vs Bangladesh a la luz de las consideraciones previas. En este contexto, el presente caso es susceptible de clasificarse con lo que REISMAN y SLOANE llaman la consequential expropriation, que se refiere a la falla del Estado de manejar adecuadamente el marco normativo.

Other "measures tantamount to expropriation" within the purview of a BIT regime prove even more elusive than creeping expropriations because they consist of the host state's failures to create, maintain and properly manage the legal, administrative and regulatory normative framework contemplated by the relevant BIT, an indispensable feature of the "favourable conditions" for investment.?"

En esta clasificación puede no existir una intención del Estado de expropiar, o al menos puede estar oculta. En uno de los ejemplos hipotéticos que REISMAN y SLOANE señalan para esta clase de expropiación indirecta mencionan que:

Local courts defer interminably decisions required by the BIT and critical to the profitability of the investment; or, because of the host state's failure to establish internal legal mechanism to accommodate a BIT regime, local courts enjoin, on the basis of that state's internal laws, investment activities previously authorized by the host state or one of its political subdivisions. ${ }^{30}$

\section{Conclusión}

El asunto Saipem no tiene que ser ignorado por los tribunales mexicanos. En efecto, la triste decisión de la Suprema Corte de Justicia de la Nación de desnaturalizar e interpretar contra legem al artículo 1424 del Código de Comercio para rechazar el principio de kompetenz-kompetenz ${ }^{31}$, hubiera podido ser motivo

29. REISMAN, MICHAEL Y SLOANE ROBERT. "indirect expropriation and its valuation in the BIT generation" En The british yearbook of international law, 2004 n.. 32.

30. Ihilem. P. 29. 
de una responsabilidad internacional del Estado mexicano si la parte frustrada hubiera sido un inversionista extranjero bajo el amparo del TLCAN. En efecto, como lo hemos visto anteriormente, no se requiere una "intención expropiatoria", sino que es suficiente que una medida tenga por consecuencia la expropiación (indirecta), tal como una interpretación judicial, aunque se haya hecho de "buena fe". Obviamente, tal situación da la apariencia de una forma de "apelación internacional", aunque los órganos internacionales refutan tal argumento. ${ }^{32} \mathrm{Sin}$ embargo, es legítimo hacerse la pregunta, cuya respuesta tiene que ser objeto de otro estudio...

31. GRAHAM, JAMES. "Mexican supreme court decisions on the authority of courts over arbitration agreements and the enforcement of awards" Neusletter arhitration, IBA, marzq de 2008, p.29; PEREZNIETO, LEONEL Y GRAHAM, JAMES. "Mexican supreme court rejects the principle of kompetenz-kompetenz", Arbitration, 2006 p.388; PEREZNIETO, LEONEL Y GRAHAM, JAMES. "El principio de la competencia arbitral en la actualidad mexicana"En: Conocimiento y cultura Juridica, 2007 p. 217; GRAHAM, JAMES Y LEAL-ISLA, CARLOS "Une atteinte discutable au principe de competence-competence" Rev $A r b, 2006$, p.1039; PEREZNIETO, LEONEL Y GRAHAM, JAMES. "Some recent international decisions on kompetenz-kompetenz and related issues" En: Revisła Latinoamericana de Mediación y Arbitraje. 2006, p. 131.

32. Véase el caso Loewen y su comentario en GRAHAM, JAMES ¿Dónde se queda la legitima expectativa...? Op. Cit. Nota !l. pp. 151 y ss. En materia penal, se puede señalar el caso Avena en el cual los Estados Unidos de América han reprochado a la Corte Internacional de Justicia de ser un "Iribunal de apelación" en materia de condenas a la pena de muerte (GRAHAM JAMES, Ĺos extranjeros condenados a muerne en los Estados Unidos de América y sus derechos consulares. I’ edición. México: UDEM, 2006. p. 23.). 